\title{
IMAGe Syndrome
}

National Cancer Institute

\section{Source}

National Cancer Institute. IMAGe Syndrome. NCI Thesaurus. Code C130988.

A condition caused by heterozygous mutation(s) in the CDKN1C gene, encoding cyclindependent kinase inhibitor $1 \mathrm{C}$, and characterized by intrauterine growth restriction, metaphyseal dysplasia, cong enital adrenal hypoplasia, and genital anomalies. 